\title{
Dinocyst distributions and stratigraphy of two Cenomanian-Turonian boundary (Upper Cretaceous) sections from the western Anglo-Paris Basin
}

\author{
BRUCE A. TOCHER' \& IAN JARVIS ${ }^{2}$ \\ ' Palynological Research Centre, Institute of Earth Studies, University of Wales, Aberystwyth, Dyfed SY23 3DB, UK. \\ ${ }^{2}$ School of Geological Sciences, Kingston University, Penrhyn Road, Kingston upon Thames, Surrey KT1 2 EE, UK.
}

\begin{abstract}
The dinoflagellate cyst distributions and stratigraphies of two representative Cenomanian/Turonian $(\mathrm{C} / \mathrm{T})$ boundary sections from the Maine and Normandy regions of northern France are described. Siliciclastic-rich sediments which characterize the Upper Cenomanian in Maine, contrast with the coeval nodular chalk and hardground lithofacies of Normandy. Both areas display a transition to marly chalks in the Lower Turonian. Dinocyst assemblages are characterized by low diversities (38 taxa) and low overall abundances, and relatively few stratigraphically significant species. The continued occurrence of Epelidosphaeridia spinosa (Cookson \& Hughes) Davey in the Upper Cenomanian of Maine is noted. Results are compared and contrasted with those from coeval sections elsewhere in the Anglo-Paris Basin. A major decline in cyst abundance and diversity is typical of the $\mathrm{C} / \mathrm{T}$ boundary interval, which is characterized by a dominance of tolerant cosmopolitan forms such as Circulodinium distinctum (Deflandre \& Cookson) Jansonius, Hystrichosphaeridium bowerbankii Davey \& Williams, Oligosphaeridium complex (White) Davey \& Williams, Odontochitina costata Alberti; emend. Clarke \& Verdier and $O$. operculata (O. Wetzel) Deflandre \& Cookson. $J$. Micropalaeontol. 14(2): 97-105, October 1995.
\end{abstract}

\section{INTRODUCTION}

The Cenomanian/Turonian $(\mathrm{C} / \mathrm{T})$ boundary marks one of the most significant periods of biotic turnover in the Mesozoic (Raup \& Sepkoski, 1982), with major changes in macro-, micro- and nannofossil assemblages occurring across the boundary interval worldwide (Bralower, 1988; Jarvis et al., 1988a; Elder, 1991; Hart \& Leary, 1991; Kennedy \& Cobban, 1991; Peryt \& Wyrwicka, 1991; Schönfeld et al., 1991; Gale et al., 1993; Harries, 1993; Robaszynski \& Gale, 1993; Ulicný et al., 1993). The causes of this turnover remain hotly debated (Corfield et al., 1990; Jeans et al., 1991; Ulicný, 1992; Orth et al., 1993), but it is associated with a major palaeoceanographic event which led to the widespread accumulation of organic-rich sediments in the ocean basins, and produced a distinctive positive carbon stable-isotope excursion in marine carbonates and organic matter (Schlanger et al., 1987; Arthur et al., 1988; Jarvis et al., 1988a; Pratt et al., 1991; Hilbrecht et al., 1992; Gale et al., 1993); the so-called C/T oceanic anoxic event (OAE2) of Schlanger \& Jenkyns (1976).

Despite such widespread interest, detailed palynological studies across the C/T boundary are still relatively rare (e.g. Jarvis et al., 1988a, b; Marshall \& Batten, 1988; Courtinat et al., 1991). The present work describes the dinoflagellate cyst distributions of two boundary successions located close to the western edge of the Anglo-Paris Basin. The sequence stratigraphy and depositional setting of this area has been described recently by Juignet \& Breton (1992). The sections studied are representative of two distinct palaeogeographic areas, the 'Maine Platform' and 'Normandy Basin'. Throughout the Cenomanian, Maine accumulated relatively thick sequences of siliciclastic sediment derived from the Armorican Massif immediately to the west. At the same time in Normandy, to the NE, only attenuated successions of pelagic chalk were deposited. However, with the progressive rise in eustatic sea-level through the Cenomanian (Haq et al., 1987; Hancock, 1989; Juignet \& Breton, 1992), sedimentological differences between the two areas declined and chalk sedimentation dominated in both areas by the Early Turonian.

Duneau (Figs 1-3), ENE of Le Mans, exposes a typical Maine sequence, with the transition from Upper Cenomanian sands and sandstones to Lower Turonian chalks. Normandy successions are exemplified by St-Sylvestre-deCormeilles near Rouen (Figs 4,5), where the $\mathrm{C} / \mathrm{T}$ transition comprises of marly and nodular chalks with well-developed hardgrounds. Twelve $20 \mathrm{~g}$ samples from Duneau and 9 samples from St-Sylvestre-de-Cormeilles were processed using standard palynological acid digestion techniques, and the resultant strew mounts were examined under a light microscope. Dinoflagellate cyst records (see Appendix 1) were plotted against detailed lithological logs and compared with macrofossil evidence to assist interpretation of the palynological data. Preparations are stored in the reference collection of the Palynological Research Centre, Institute of Earth Studies, University of Wales, Aberystwyth, UK.

\section{DUNEAU}

Les Fosses Blanches Quarry (Terres Blanches Marl Pit of Doré et al., 1987; coordonnées Lambert of the Institut géographique National de France: $x=464,18 ; y=341,67)$ is situated $1 \mathrm{~km} \mathrm{SW}$ of the village of Duneau (Fig. 1), $25 \mathrm{~km}$ ENE of Le Mans, Sarthe. The area lies within the Cenomanian type region (Juignet, 1980; Birkelund et al., 1984), and sections in the vicinity of the village have been used to define the top of the stage (Juignet et al., 1973; Robaszynski, 1984). Approximately $14 \mathrm{~m}$ of CenomanianTuronian sediments (Figs 2,3) are exposed at Les Fosses 


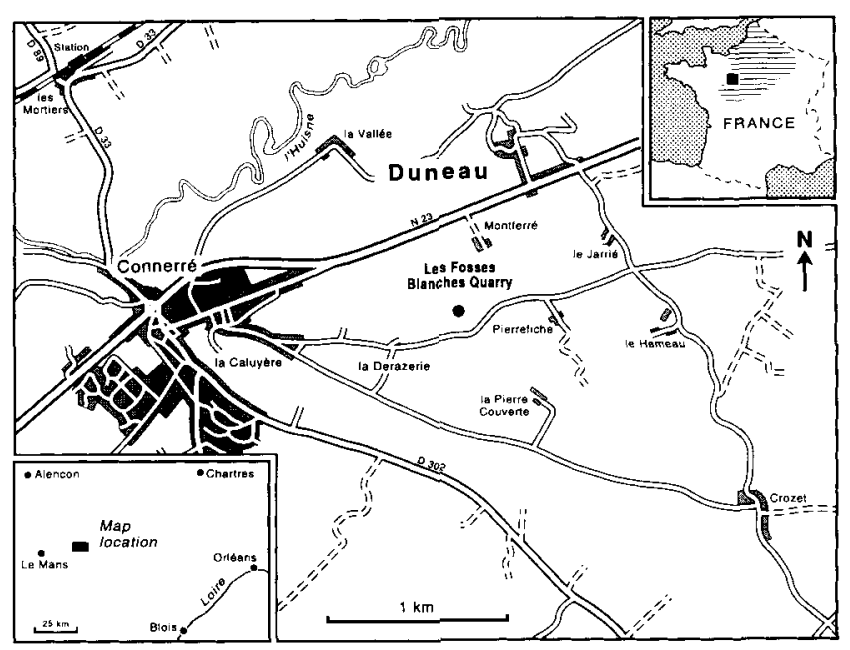

Fig. 1. Location maps for Les Fosses Blanches Quarry, Duneau. The regional map (upper right) shows the position of the study area in relation to the Cretaceous Anglo-Paris Basin (horizontal ornament).

\section{Lithological key:}

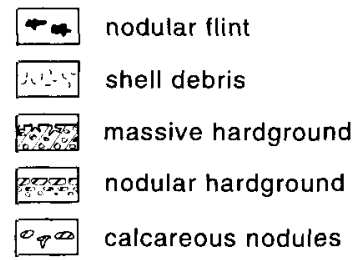

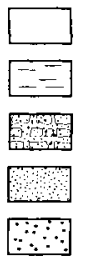

Fig. 2. Key to main lithologies occurring in the Duneau and St-Sylvestre-de-Cormeilles sections (Figs 3, 5).

Blanches, in a small working chalk quarry and an adjacent sand pit. The locality displays one of the best exposures of Lower Turonian in the area (Juignet \& Lebert, 1987); parts of the section have been described previously by Juignet (1974) and Woodroof (1981).

\section{Lithostratigraphy}

The sand pit exposes the upper part of the Sables du Perche, yellow, medium-grained, glauconitic sands containing large calcareous nodules which give the sediment a distinctive rubbly appearance. The top of the formation is taken at the surface of a blocky hardground (Fig. 3), Duneau Hardground 2 of Juignet (1974), which occurs at the top of the sand pit. This hardground forms the floor of the chalk quarry, where it is overlain by a thin sequence of glauconite- and quartz-rich, marly chalks, assigned to the Marnes à 'Ostrea' biauriculata. The contact with the overlying Sables à Catopygus obtusus is sharp. The latter formation is represented here by $30 \mathrm{~cm}$ of grey nodular indurated sandy limestone, the top of which corresponds to the Bousse Hardground (Juignet, 1974; Juignet \& Breton, 1992).

The overlying Mézieres erosion surface, which generally marks the top of the Sables à $C$. obtusus, appears to have been superimposed onto the surface of the Bousse
Hardground in this section, although the two surfaces are separated by $40 \mathrm{~cm}$ of sandy limestone in exposures at Chemin du Grand-Crozet, also near Duneau (Juignet 1974). Above the Sables à $C$. obtusus lies the Craie à Terebratella carantonensis, glauconitic marly chalks with an abundant macrofauna resting on a basal layer rich in quartz gravel. This formation passes upwards without a marked break into monotonous grey marly chalks of the Craie à 'Inoceramus' labiatus. Rare calcareous nodules and occasional small flints are present in the upper part of the succession.

\section{Biostratigraphy}

No macrofauna was collected from the Sables du Perche at this quarry, although terebratulid brachiopods Gemmarcula menardi (Lamark) and internal moulds of bivalves have been recorded (Guillier, 1886; Juignet et al., 1973; Juignet, 1974) from the top of the formation at nearby exposures (Chemin du Grand-Crozet and Duneau village sections). The Sables du Perche are generally regarded as lying within the low Upper Cenomanian Calycoceras guerangeri ammonite Zone, although all three samples (Dun. 1-3) collected for palynological analysis proved to be barren.

Abundant specimens of Pycnodonte biauriculata (Lamark) oysters occur in the soft glauconitic marly chalks (Marnes à ' $O$ '. biauriculata) that overlie the Sables du Perche at Duneau. Correlation with ammonite-bearing sections elsewhere in the region (Juignet, 1974) indicates that these chalks also fall within the upper $C$. guerangeri Zone. A sample (Dun. 4) collected from this level contained a low diversity and low abundance dinoflagellate cyst assemblage (Fig. 3), comprising only 17 species and less than 100 individuals. None of the cysts recorded is particularly significant stratigraphically over this interval, although the occurrence of a single specimen of Epelidosphaeridia spinosa (Cookson \& Hughes) Davey is worthy of note. The last common occurrence of this species is generally regarded (Foucher, 1981; Costa \& Davey, 1992) as indicative of the top of the Middle Cenomanian. However, recent work on C/T boundary sections in southern England (Tocher \& Jarvis, unpublished data) confirms that rare specimens are found in the Upper Cenomanian.

The Sables à $C$. obtusus are represented by a thin indurated limestone containing abundant Rhynchostreon suborbiculatum (Lamarck) oysters. There are no other macrofaunal records for this level at Les Fosses Blanches Quarry, but a relatively rich assemblage has been described (Juignet et al., 1973; Juignet, 1974) from the Sables à $C$. obtusus exposed in the Chemin du Grand-Crozet section. This fauna is typical of the mid-Upper Cenomanian Metoicoceras geslinianum ammonite Zone. Only five species of dinoflagellate cysts were recorded from this formation (Fig. 3; Dun. 5), none of which is stratigraphically significant.

The Craie à $T$. carantonensis yields Sciponoceras sp., common Rastellum (Arctostrea) carinatum (Lamarck) and Pycnodonte sp. oysters, plus terebratulid brachiopods. Several remanié specimens of ammonites, $M$. cf. geslinianum (d'Orbigny), Sciponoceras gracile (Shumard) and Calycoceras (Calycoceras) naviculare (Mantell) have been 


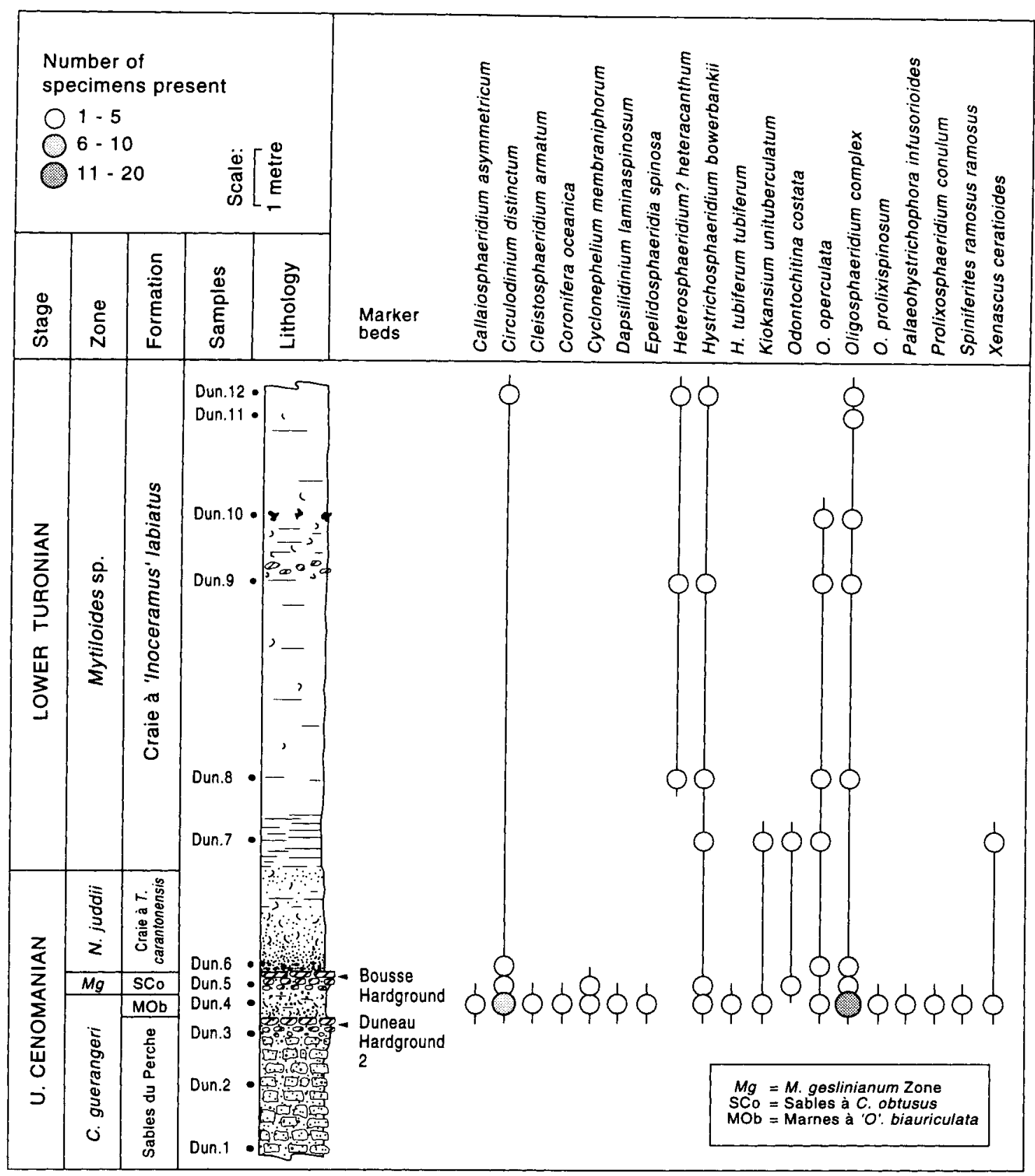

Fig. 3. Stratigraphy and dinocyst distribution across the Cenomanian-Turonian boundary at Les Fosses Blanches Quarry, Duneau. See Fig. 2 for lithological key.

collected (Juignet et al., 1973; Juignet, 1974) from the Chemin du Grand-Crozet section. However, Wright \& Kennedy (1981) observed that the only indigenous ammonite which had been found in this formation was a single specimen of Neocardioceras juddii juddii (Barrois \& Guerne) from Le Moulin Ars Quarry near St. Calais, Sarthe, which is definitive of the topmost Upper Cenomanian $N$. juddii Zone. A palynological sample collected from the base of the formation (Fig. 3; Dun. 6) contained only three long-ranging dinoflagellate cyst species.
Juignet (1974) recorded numerous specimens of Mytiloides sp. bivalves and Orbirhynchia cuvieri (d'Orbigny) brachiopods from the marly chalks overlying the Craie à $T$. carantonensis, indicating an Early Turonian age for the Craie à 'Inoceramus' labiatus. Woodroof (1981) placed the lower part of the latter formation in his Mytiloides ef. opalensis $[=M$. columbianus (Heinz), see Hancock, 1991; $=M$. kossmati (Heinz), see Walaszczyk, 1992] Zone, while the uppermost $2 \mathrm{~m}$ of the section (Fig. 3; including our samples Dun. 11, 12) lie within his $M$. mytiloides Zone. Six 
palynological samples (Dun. 7-12) taken from the Craie à 'Inoceramus' labiatus produced only occasional specimens of mostly cosmopolitan taxa such as Circulodinium distinctum (Deflandre \& Cookson) Jansonius, Heterosphaeridium? heteracanthum (Deflandre \& Cookson) Eisenack \& Kjellstrom, Hystrichosphaeridium bowerbankii Davey \& Williams, Odontochitina operculata $(\mathrm{O}$. Wetzel) Deflandre \& Cookson and Oligosphaeridium complex (White) Davey \& Williams.

\section{ST-SYLVESTRE-DE-CORMEILLES}

The Bois du Gallet Marl Pit $(x=460,56 ; y=173,10)$ is a large quarry situated within the Commune de St-Sylvestrede-Cormeilles, Eure (Fig. 4), which exposes $12 \mathrm{~m}$ of marly chalks. The quarry was noted as the only working marl pit in the area by Juignet (1971), but has subsequently been abandoned. The upper part of the succession was described by Juignet (1974).

\section{Lithostratigraphy}

The section (Fig. 5) displays the upper part of the Craie d'Antifer (following the terminology of Juignet \& Breton, 1992; = Craie à Actinocamax plenus of the older literature) and the base of the Craie à 'Inoceramus' labiatus. The Craie d'Antifer is characterized by light grey marly chalks separated by two massive-topped nodular hardgrounds with glauconitized surfaces which are penetrated by numerous Thalassinoides burrows containing unlithified chalk fills. The lower hardground is correlated with Antifer Hardground 2 of Juignet (1974); the upper corresponds to Antifer Hardground 3.

Approximately $3 \mathrm{~m}$ of light grey nodular chalks overlie the surface of Antifer Hardground 3 and are followed by a thicker succession of creamy white marly chalks with occasional bands of grey nodular flints. This sequence constitutes the Craie à 'l.' labiatus.

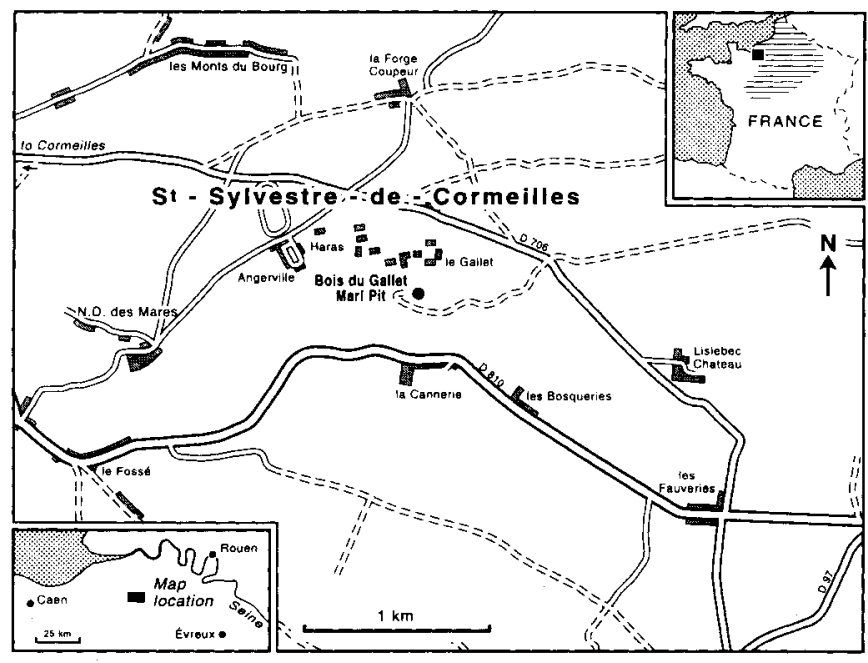

Fig. 4. Location maps for Bois du Gallet Marl Pit, St-Sylvestre-deCormeilles. The regional map (top right) shows position of the study area in relation to the Cretaceous Anglo-Paris Basin (horizontal ornament).

\section{Biostratigraphy}

No diagnostic macrofauna was found in the Craie d'Antifer at this locality. However, correlation with faunally richer successions in the Lieuvin and the Pays de Caux (Juignet, 1974), indicates that the formation lies within the $M$. geslinianum Zone (mid-Upper Cenomanian). Three samples (StS. 1-3) were processed for their palynomorph content, each yielding a moderately diverse (up to 25 taxa) but low abundance dinoflagellate cyst assemblage (Fig. 5). The lower two samples (StS. 1, 2) contain common Odontochitina operculata (Pl. 1, fig. 11), while sample StS. 3 is dominated by $O$. costata Alberti; emend. Clarke \& Verdier (Pl. 1, fig. 13), and to a lesser extent, Cyclonephelium compactum Deflandre \& Cookson. The presence of the latter species suggests that this formation is Late Cenomanian $(C$. guerangeri ammonite Zone) or younger (Marshall \& Batten, 1988); this is supported (see Jarvis et al., 1988a) by the occurrence of Kallosphaeridium? ringnesiorum (Manum \& Cookson) Helby (Pl. 1, fig.9) in the basal sample (StS. 1).

Specimens of Cenomanian Inoceramus pictus (J. de C. Sowerby) bivalves were recovered from the lowest beds of the Craie à ' $I$.' labiatus. The base of the Turonian is marked by the incoming of Mytiloides sp. bivalves which appear immediately above the second nodular chalk in the succession (Fig. 5). The base of the formation corresponds, therefore, to the $N$. juddii Zone (Wright \& Kennedy, 1981). Two samples (StS. 4-5) taken from this interval yielded very low abundance and low diversity cyst assemblages comprising only a few specimens of Circulodinium distinctum (Pl. 1, fig. 2), Cyclonephelium clathromarginatum Cookson \& Eisenack, C. compactum, C. membraniphorum Cookson \& Eisenack (Pl. 1, fig. 3), Hystrichosphaeridium bowerbankii, K.? ringnesiorum, Odontochitina costata, $O$. operculata and Oligosphaeridium complex.

Occasional Mytiloides sp. occur throughout the upper beds in the succession. Four Turonian samples were processed for palynomorphs (StS. 6-9) but yielded only relatively poor dinoflagellate cyst assemblages. The first appearance of the Lower Turonian marker Senoniasphaera rotundata Clarke \& Verdier (StS. 8; Pl. 1, fig. 12) and the continued presence of Kiokansium unituberculatum (Tasch) Stover \& Evitt suggest that the top of the studied section is no younger than Early Turonian (Foucher, 1981; Tocher \& Jarvis, 1987; Jarvis et al., 1988a).

\section{DISCUSSION}

Samples analysed from both areas are characterized by low diversity (a total of 38 taxa) and low abundance dinoflagellate cyst assemblages, although somewhat better recoveries were obtained from the Normandy section (St-Sylvestre-de-Cormeilles). Few of the key Upper Cenomanian-Lower Turonian marker species (Foucher, 1981; Tocher \& Jarvis, 1987; Jarvis et al. 1988a) were recorded, making precise dating of these sections on the basis of their palynomorph content difficult. This is partly a consequence of the relatively short stratigraphic interval sampled, since in other studies (Robaszynski et al., 1982; Tocher \& Jarvis, 1987; Jarvis et al., 1987, 1988a) the 


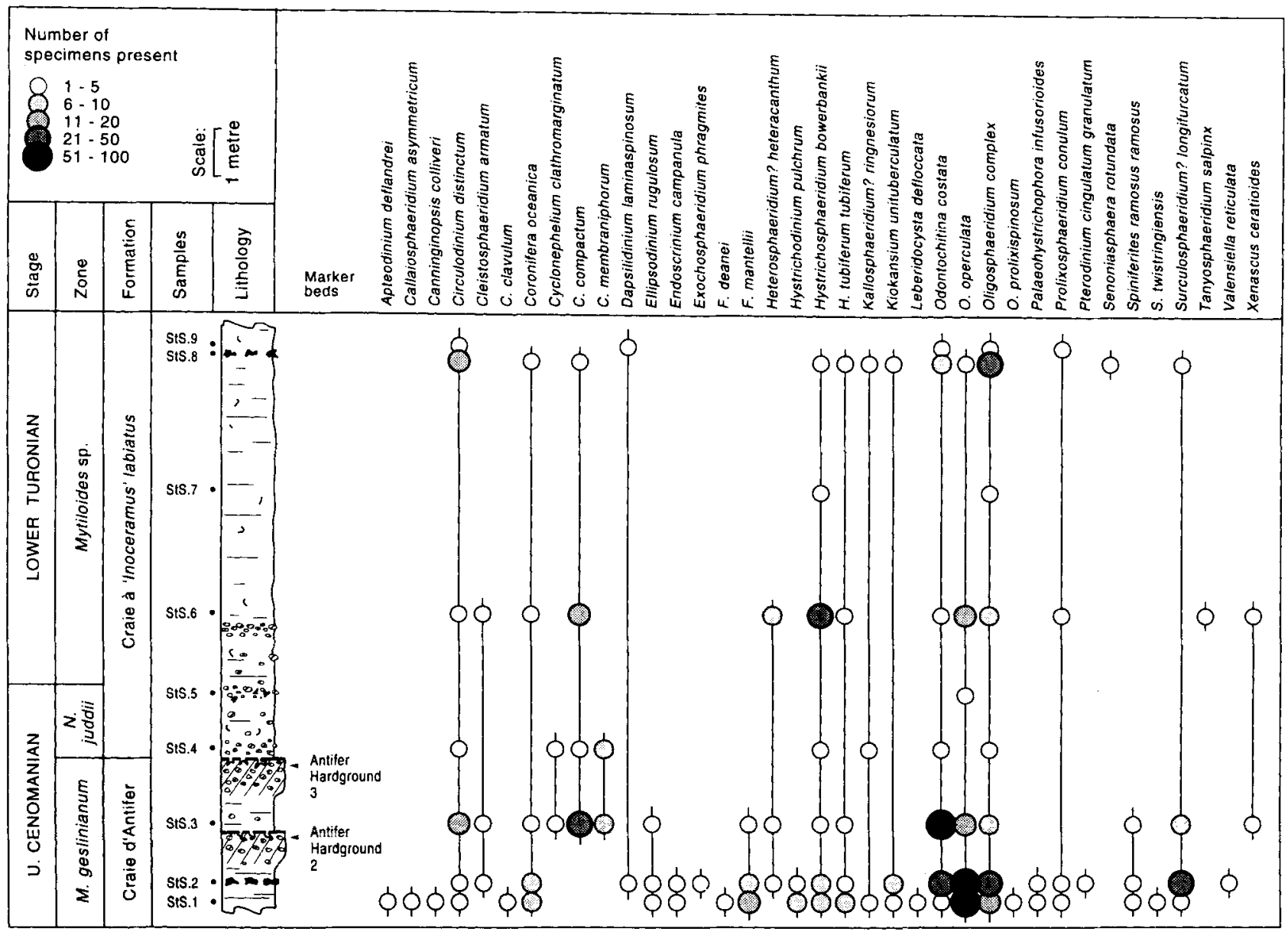

Fig. 5. Stratigraphy and palynomorph distribution across the Cenomanian-Turonian boundary at Bois du Gallet Marl Pit, St-Sylvestrede-Cormeilles. See Fig. 2 for lithological key.

incoming of low Turonian marker species has been shown to occur many metres above the stage boundary.

The very limited assemblages recovered from the lower part of the Duneau section (Fig. 3) can be explained, at least in part, by the composition of the sediments. The sandy nature of the section, with well-developed hardgrounds is consistent with the marginal, relatively shallow-water setting for $\mathrm{C} / \mathrm{T}$ deposition in Maine. Similarly impoverished assemblages have been described (Jarvis et al., 1988b) from coeval sands and limestones developed adjacent to the Cornubian Massif, exposed at Hooken Cliffs in SE Devon, England.

Looking at the cyst assemblages as a whole (particularly abundance and diversity patterns) it is possible to see other similarities between the distributions recorded here and those described from Devon (Jarvis et al., 1988b) and Dover (Jarvis et al., 1988a). This is particularly true of assemblages from St-Sylvestre-de-Cormeilles and Dover where the uppermost Cenomanian is characterized by relatively high numbers of $O$. operculata and $O$. costata, and the Lower
Turonian is typified by very low abundance, low diversity assemblages dominated by long-ranging taxa, particularly $C$. distinctum, H. bowerbankii, $O$. operculata and $O$. complex. However, cysts disappear entirely from the uppermost Cenomanian and basal Turonian sediments at Dover, whereas at both Duneau and St-Sylvestre-de-Cormeilles, despite a major decline, it is possible to find rare cysts at this level.

The continued occurrence of dinoflagellate cysts across the $\mathrm{C} / \mathrm{T}$ boundary in western France might be a consequence of the marginal depositional setting of the area. More turbulent water conditions and better mixing are likely to have led to the region being less affected by the major palaeoceanographic changes which have been inferred for deeper water areas within the Anglo-Paris Basin and elsewhere (e.g. Schlanger et al., 1987; Jarvis et al., 1988a; Hilbrecht et al., 1992; Ulicný et al., 1993). Perhaps more importantly, however, major lithological differences between the two areas mean that palynomorphs have a higher preservation potential in the marlier chalks of the French 

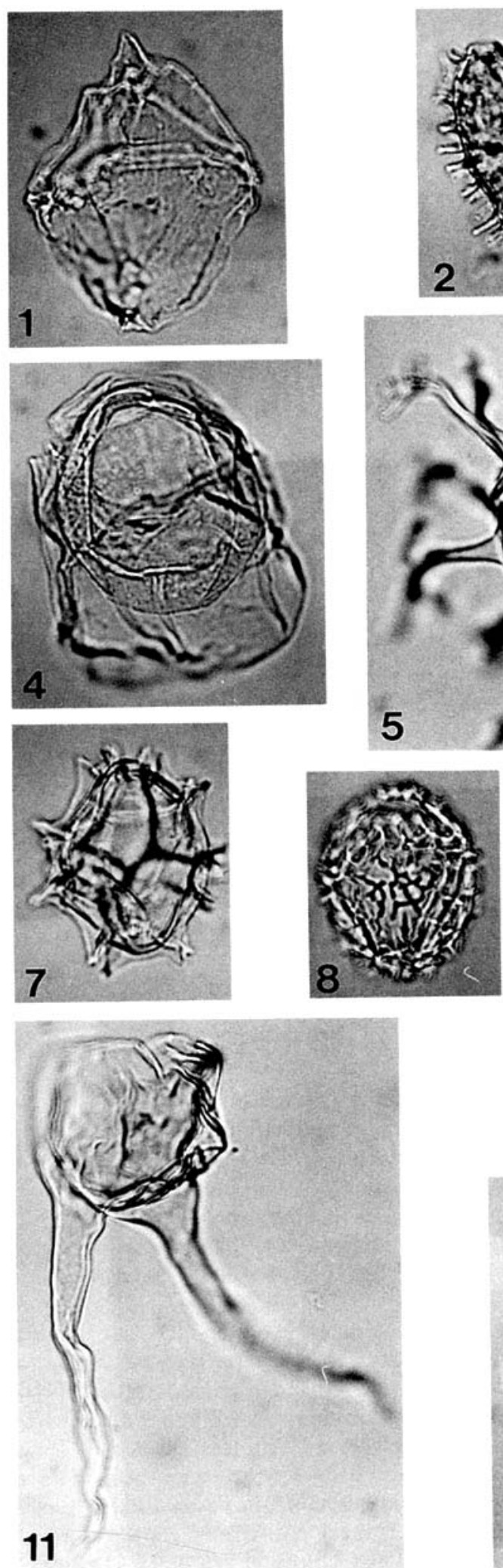
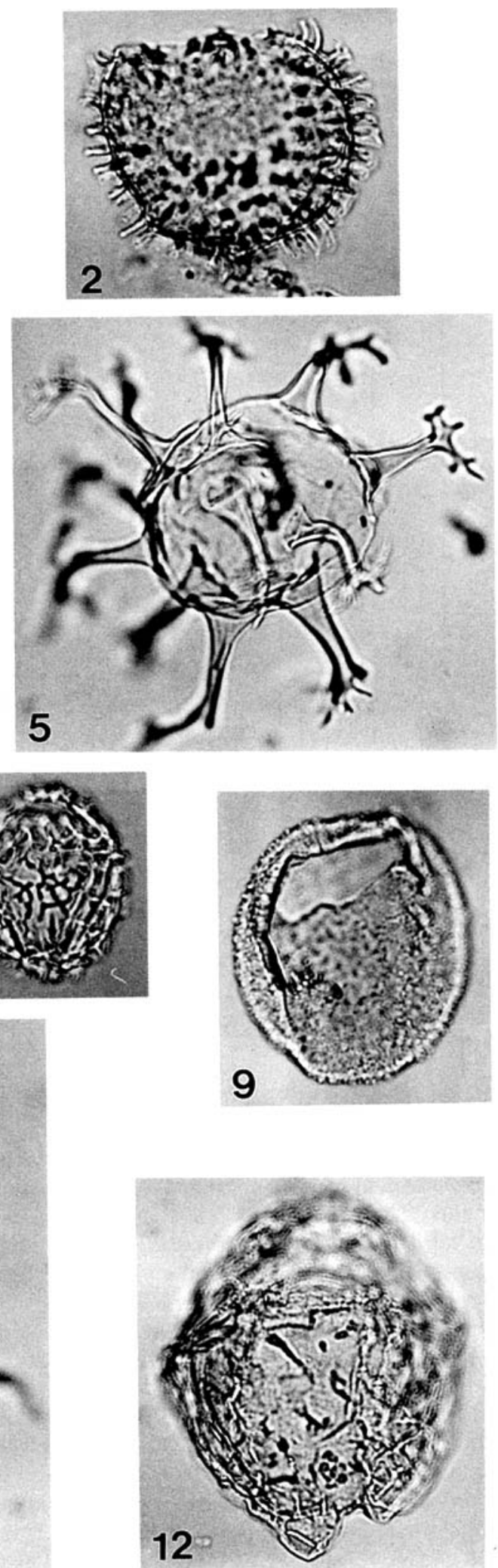

Plate 1
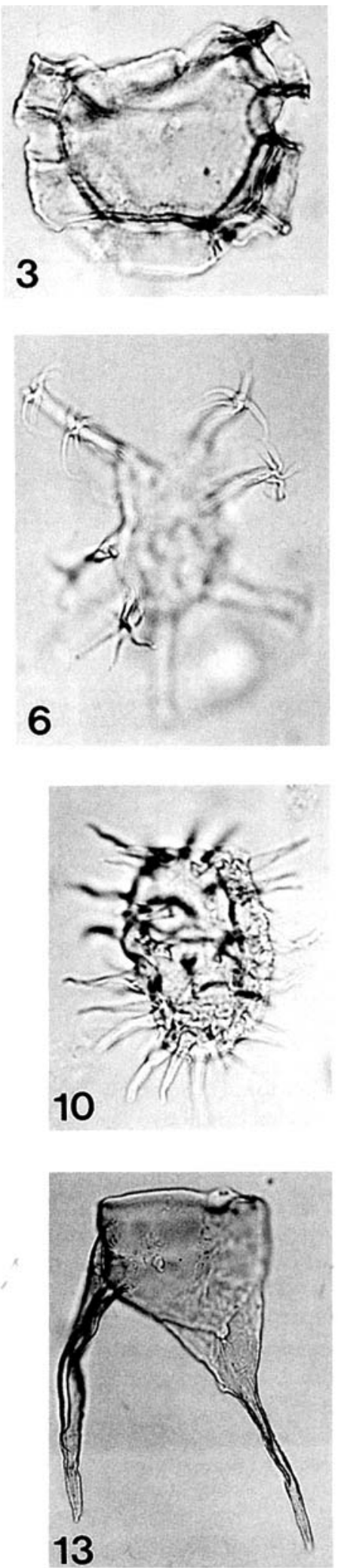
localities, than in the highly nodular, reworked and cemented limestones (Melbourn Rock Beds) which constitute the $\mathrm{C} / \mathrm{T}$ boundary interval at Dover.

\section{CONCLUSIONS}

Dinoflagellate cyst assemblages recovered from samples taken across representative Cenomanian/Turonian boundary sections in Maine and Normandy are of low abundance and low diversity. Stratigraphic marker species are rare, making precise dating very difficult on the basis of palynomorphs alone. However, comparison with published data from coeval marginal sections elsewhere in the Anglo-Paris Basin show broad similarities both in terms of the lithofacies present and overall cyst distribution patterns.

\section{ACKNOWLEDGEMENTS}

This work was initiated in the School of Earth Sciences, University of Greenwich (formerly part of City of London Polytechnic). Subsequent support from the University of Wales, Aberystwyth and Kingston University is gratefully acknowledged.

\section{Manuscript received November 1993 Manuscript accepted June 1994}

\section{APPENDIX 1}

List of taxa recorded. See Lentin \& Williams (1993) for full reference details. Locality records $($ Dun. $=$ Duneau; StS. $=$ St-Sylvestre-de-Cormeilles) and figured taxa (details in parentheses) are indicated.

Apteodinium deflandrei (Clarke \& Verdier, 1967) LucasClark, 1987; StS.

Callaiosphaeridium asymmetricum (Deflandre \& Courteville, 1939) Davey \& Williams, 1966; Dun., StS.

Canninginopsis colliveri (Cookson \& Eisenack, 1960)

Backhouse, 1988; StS.

Circulodinium distinctum (Deflandre \& Cookson, 1955)

Jansonius, 1986; Dun., StS (P1. 1, fig. 2).

Cleistosphaeridium armatum (Deflandre, 1937) Davey, 1969;

Dun., StS.

C. clavulum (Davey, 1969) Below, 1982; StS.

Coronifera oceanica Cookson \& Eisenack, 1958; emend. May, 1980; Dun., StS.
Cyclonephelium clathromarginatum Cookson \& Eisenack, 1962; StS.

C. compactum Deflandre \& Cookson, 1955; StS.

C. membraniphorum Cookson \& Eisenack, 1962; Dun., StS (P1. 1, fig. 3).

Dapsilidinium laminaspinosum (Davey \& Williams, 1966) Lentin \& Williams, 1981; Dun., StS.

Ellipsodinium rugulosum Clarke \& Verdier, 1967; StS (PI. 1, fig. 8).

Endoscrinium campanula (Gocht, 1959) Vozzhennikova, 1967; StS (Pl. 1, fig. 1).

Epelidosphaeridia spinosa (Cookson \& Hughes, 1964) Davey, 1969; Dun.

Exochosphaeridium phragmites Davey et al., 1966; StS.

Florentinia deanei (Davey \& Williams, 1966) Davey \& Verdier, 1973; StS.

F. mantellii (Davey \& Williams, 1966) Davey \& Verdier, 1973; StS.

Heterosphaeridium? heteracanthum (Deflandre \& Cookson, 1955) Eisenack \& Kjellstrom, 1971; Dun., StS.

Hystrichodinium pulchrum Deflandre, 1935; StS.

Hystrichosphaeridium bowerbankii Davey \& Williams, 1966; Dun., StS.

H. tubiferum tubiferum (Ehrenberg, 1838) Deflandre, 1937; emend. Davey \& Williams, 1966; Dun., StS.

Kallosphaeridium? ringnesiorum (Manum \& Cookson, 1964) Helby, 1987; Dun., StS (Pl. 1, fig. 9).

Kiokansium unituberculatum (Tasch, 1964) Stover \& Evitt, 1978; Dun., StS.

Leberidocysta defloccata (Davey \& Verdier, 1973) Stover \& Evitt, 1978; StS (Pl. 1, fig. 4).

Odontochitina costata Alberti, 1961; emend. Clarke \& Verdier, 1967; Dun., StS (PI. 1, fig. 13).

O. operculata (O. Wetzel, 1933) Deflandre \& Cookson, 1955; Dun., StS (PI. 1, fig. 11).

Oligosphaeridium complex (White, 1842) Davey \& Williams, 1966; Dun., StS (Pl. 1, fig. 5).

O. prolixispinosum Davey \& Williams, 1966; Dun., StS (Pl. 1, fig. 6).

Palaeohystrichophora infusorioides Deflandre, 1935; Dun., StS.

Prolixosphaeridium conulum Davey, 1969; Dun., StS (Pl. 1, fig. 10).

\section{Explanation of Plate 1}

Representative Upper Cenomanian-Lower Turonian dinoflagellate cysts from Duneau and St-Sylvestre-de-Cormeilles. Figure captions include species name, author(s), sample number, preparation number, and England Finder co-ordinates. Samples are deposited in the reference collection of the Palynological Research Centre, Institute of Earth Studies, Aberystwyth. All specimens were photographed at $\times 500$, unless otherwise stated.

Fig. 1. Endoscrinium campanula (Gocht, 1959) Vozzhennikova, 1967, StS. 1, WHP/324, Y44. Fig. 2. Circulodinium distinctum (Deflandre \& Cookson, 1955) Jansonius, 1986, StS. 3, WHP/326, G47/4. Fig. 3. Cyclonephelium membraniphorum Cookson \& Eisenack, StS. 4, WHP/327, O55. Fig. 4. Leberidocysta defloccata (Davey \& Verdier, 1973) Stover \& Evitt, 1978, StS. 1, WHP/324, W30. Fig. 5. Oligosphaeridium complex (White, 1842) Davey \& Williams, 1966, StS. 1, WHP/324, X36/3. Fig. 6. Oligosphaeridium prolixispinosum Davey \& Williams, 1966, StS. 1, WHP/324, Q55. Fig. 7. Pterodinium cingulum (O. Wetzel, 1933) granulatum (Clarke \& Verdier, 1967) Lentin \& Williams, 1981, StS. 2, WHP/325, V49/4. Fig. 8. Ellipsodinium rugulosum Clarke \& Verdier, 1967, StS. 1, WHP/324, K59/1. Fig. 9. Kallosphaeridium? ringnesiorum (Manum \& Cookson, 1964) Helby, 1987, StS. 1, WHP/324, T40. Fig. 10. Prolixosphaeridium conulum Davey, 1969, StS.2, WHP/325, K44/4. Fig. 11. Odontochitina operculata (O. Wetzel, 1933) Deflandre \& Cookson, 1955, StS. 1, WHP/324, J43/2. Fig. 12. Senoniasphaera rotundata Clarke \& Verdier, 1967, StS. 8, WHP/331, S35/2. Fig. 13. Odontochitina costata Alberti, 1961; emend. Clarke \& Verdier, 1967, StS. 2, WHP/325, H33/2 (×250). 
Pterodinium cingulum (O. Wetzel, 1933) granulatum (Clarke \& Verdier, 1967) Lentin \& Williams, 1981; StS (Pl. 1, fig. 7). Senoniasphaera rotundata Clarke \& Verdier, 1967; StS (Pl. 1, fig. 12).

Spiniferites ramosus ramosus (Ehrenberg, 1838) Mantell, 1854; Dun., StS.

S. twistringiensis (Maier, 1959) Fensome et al., 1990; Dun., StS.

Surculosphaeridium? longifurcatum (Firtion, 1952) Davey et al., 1966; StS.

Tanyosphaeridium salpinx Norvick in Norvick \& Burger, 1976; StS.

Valensiella reticulata (Davey, 1969) Courtinat, 1989; StS.

Xenascus ceratioides (Deflandre, 1937) Lentin \& Williams, 1973; Dun., StS.

\section{REFERENCES}

Arthur, M. A., Dean, W. E. \& Pratt, L. M. 1988. Geochemical and climatic effects of increased marine organic carbon burial at the Cenomanian/Turonian boundary, Nature, 335: 714-717.

Birkelund, T., Hancock, J. M., Hart, M. B., Rawson, P. F., Remane, J., Robaszynski, F., Schmid, F. \& Surlyk, F. 1984. Cretaceous stage boundaries - Proposals. Bulletin of the Geological Society of Denmark, 33: 3-20.

Bralower, 1988. Calcareous nannofossil biostratigraphy and assemblages of the Cenomanian-Turonian boundary interval: implications for the origin and timing of oceanic anoxia. Paleoceanography, 3: 275-316.

Courtinat, B., Crumière, J. -P., Méon, H. \& Schaaf, A. 1991. Les associations de kystes de dinoflagellés du Cénomanien-Turonien de Vergons (Bassin Vocontien, France). Geobios, 24: 649-666.

Corfield, R. M., Hall, M. A. \& Brasier, M. D. 1990 . Stable isotope evidence for foraminiferal habitats during the development of the Cenomanian-Turonian oceanic anoxic event. Geology, 18: $175-178$.

Costa, L. I. \& Davey, R. J. 1992. 3. Dinoflagellate cysts of the Cretaceous System. In Powell, A. J. (Ed) A Stratigraphic Index of Dinoflagellate Cysts, 99-154. Chapman \& Hall, London.

Doré, F., Pareyn, C., Larsonneur, C., Rioult, M. \& Juignet, P. 1987. Guides Géologiques Régionaux: Normandie Maine (2nd Ed.), 216pp. Masson, Paris.

Elder, W. P. 1991. Molluscan paleoecology and sedimentation patterns of the Cenomanian-Turonian extinction interval in the southern Colorado Plateau region. Geological Society of America Special Paper, 260: 113-137.

Foucher, J. -C. 1981. Kystes de dinoflagellés du Crétacé moyen européen: proposition d'une échelle biostratigraphique pour le domain nord-occidental. Cretaceous Research, 2: 331-338.

Gale, A. S., Jenkyns, H. C., Kennedy, W. J. \& Corfield, R. M. 1993. Chemostratigraphy versus biostratigraphy: data from around the Cenomanian-Turonian boundary. Journal of the Geological Society, 150: 29-32.

Guillier, 1886. Géologie du Département de la Sarthe, 423pp. Monnoyer, Le Mans.

Hancock, J. M. 1989. Sea-level changes in the British region during the Late Cretaceous. Proceedings of the Geologists' Association, 100: $565-594$.

Hancock, J. M. 1991. Ammonite scales for the Cretaceous system. Cretaceous Research, 12: 159-291.

Haq, B. U., Hardenbol, J. \& Vail, P. 1987. Chronology of fluctuating sea levels since the Triassic. Science, 235: 1156-1167.

Harries, P. J. 1993. Dynamics of survival following the Cenomanian-Turonian (Upper Cretaceous) mass extinction event. Cretaceous Research, 14: 563-583.

Hart, M. B. \& Leary, P. N. 1991. Stepwise mass extinctions: the case for the Late Cenomanian event. Terra Nova, 3: 142-147.

Hilbrecht, H., Hubberten, H.-W. \& Oberhänsli, H. 1992. Biogeography of planktonic foraminifera and regional carbon isotope variation: productivity and water masses in Late Cretaceous Europe. Palaeogeography Palaeoclimatology Palaeoecology, 92: 407-421.

Jarvis, I., Carson, G. A., Cooper, M. K. E., Hart, M. B., Horne, D., Leary, P. N., Rosenfeld, A. \& Tocher, B. A. 1988a. Microfossil assemblages and the Cenomanian-Turonian (late Cretaceous) Oceanic Anoxic Event. Cretaceous Research, 9: 3-103.

Jarvis, I., Carson, G. A., Hart, M. B., Leary, P. N. \& Tocher, B. A. 1988b. The Cenomanian-Turonian (late Cretaceous) anoxic event in SW England: evidence from Hooken Cliffs, near Beer, SE Devon. Newsletter on Stratigraphy, 18: 147-164.

Jarvis, I., Leary, P. N. \& Tocher, B. A. 1987. Mid-Cretaceous (Albian-Turonian) stratigraphy of Shapwick Grange Quarry, SE Devon, England. Mesozoic Research, 1: 119-134.

Jeans, C. V., Long, D., Hall, M. A., Bland, D. J. \& Cornford, C. 1991. The geochemistry of the Plenus Marls at Dover, England: evidence of fluctuating oceanographic conditions and of glacial control during the development of the Cenomanian-Turonian $\delta^{13} \mathrm{C}$ anomaly. Geological Magazine, 128: 603-632.

Juignet, P. 1971. Carte géologique de la France à 1/50,000, 122: Brionne, et notice explicative. Bureau de Recherches géologiques et minières, 8pp.

Juignet, P. 1974. La transgression crétacée sur la bordure orientale du Massif armorican. Thèse de Doctorat d'état, L'Université de Caen, 806pp.

Juignet, P. 1980. Cénomanien. In Cavelier, C. \& Roger, J. (Eds) Les Étages Français et leurs stratotypes, Mémoire Bureau de Recherches géologiques et minières, 109: 130-138.

Juignet, P. \& Breton, G. 1992. Mid-Cretaceous sequence stratigraphy and sedimentary cyclicity in the western Paris Basin. Palaeogeography Palaeoclimatology Palaeoecology, 91: 197-218.

Juignet, P., Kennedy, W. J., \& Wright, C. W. 1973. La limite Cénomanien-Turonien dans la région du Mans (Sarthe). Stratigraphie et paléontologie. Annales de Paléontologie Invertebre, 59: 209-242.

Juignet, P. \& Lebert, A. 1987. Cartes géologiques de la France à 1/50,00, 323: La Ferté-Bernard, et notice explicative, 36pp.

Kennedy, W. J. \& Cobban, W. A. 1991. Stratigraphy and interregional correlation of the Cenomanian-Turonian transition in the Western Interior of the United States near Pueblo, Colorado, a potential boundary stratotype for the base of the Turonian stage. Newsletter on Stratigraphy, 24: 1-33.

Lentin, J. K., \& Williams, G. L. 1993. Fossil dinoflagellates: index to genera and species. American Association of Stratigraphic Palynologists Contributions Series, 28: 856p.

Marshall, K. L. \& Batten, D. J. 1988. Dinoflagellate cyst associations in Cenomanian-Turonian black shale sequences of northern Europe. Review of Palaeobotany and Palynology, 54: 85-103.

Orth, C. J., Attrep Jr., M., Quintana, L. R., Elder, W. P., Kauffman, E. G., Diner, R. \& Villamil, T. 1993. Elemental abundance anomalies in the late Cenomanian extinction interval: a search for source(s). Earth and Planetary Science Letters, 117: 189-204.

Peryt, D. \& Wyrwicka, K. 1991. The Cenomanian-Turonian oceanic anoxic event in SE Poland. Cretaceous Research, 12: 65-80.

Pratt, L. M., Force, E. R. \& Pomerol, B. 1991. Coupled manganese and carbon-isotopic events in marine carbonates at the Cenomanian-Turonian boundary. Journal of Sedimentary Petrology, 61: $370-383$.

Raup, D. M. \& Sepkoski, J. J. 1982. Mass extinction in the marine fossil record. Science, 215: 1501-1503.

Robaszynski, F. 1984. The Albian, Cenomanian and Turonian Stages and their type regions. Bulletin of the Geological Society of Denmark, 33: 191-198.

Robaszynski, F., Alcayde, G., Amédro, F., Baddilet, G., Damotte, R., Foucher, J. -C., Jardine, S., Legoux, O., Manivit, H., Monciardini, C. \& Sornay, J. 1982. Le Turonien de la région-type: Saumurois et Touraine: stratigraphie, biozonations, sedimentologie. Bulletin Centres de Recherches Exploration-Production Elf-Aquitaine, 6: 119-225. 
Robaszynski, F. \& Gale, A. S. 1993. The Cenomanian-Turonian boundary: a discussion held at the final session of the colloquium on Cenomanian-Turonian boundary events, Grenoble, 26th May 1991 (France). Cretaceous Research, 14: 607-611.

Schlanger, S. O., Arthur, M. A., Jenkyns, H. C. \& Scholle, P. A. 1987. The Cenomanian-Turonian Oceanic Anoxic Event: I. Stratigraphy and distribution of organic carbon-rich beds and the marine $\delta^{13} \mathrm{C}$ excursion. In Brooks, J. \& Fleet, A. (Eds), Marine Petroleum Source Rocks, Geological Society, London, Special Publication, 26: 371-399.

Schlanger, S. O. \& Jenkyns, H. C. 1976. Cretaceous oceanic anoxic events: causes and consequences. Geologie en Mijnbouw, 55: $179-170$.

Schönfeld, J., Schiebel, R. \& Timm, S. 1991. The Rötplaner (Upper Cenomanian to Lower Turonian) of Baddeckenstedt (northwestern Germany): lithology, geochemistry, foraminifers and stratigraphic correlation. Meyniana, 43: 73-95.

Tocher, B. A. \& Jarvis, I. 1987. Dinoflagellate cysts and stratigraphy of the Turonian (Upper Cretaceous) chalk near Beer, southeast
Devon, England. In Hart, M. B. (Ed), Micropalaeontology of Carbonate Environments, 138-175. Ellis Horwood, Chichester.

Ulicný, D. 1992. Discussion on the fluctuating oceanographic conditions and glacial control across the Cenomanian-Turonian boundary. Geological Magazine, 129: 637-640.

Ulicný, D., Hladiková, J. \& Hradecká, L. 1993. Record of sea-level changes, oxygen depletion and the $\delta^{13} \mathrm{C}$ anomaly across the Cenomanian-Turonian boundary, Bohemian Cretaceous Basin. Cretaceous Research, 14: 211-234.

Walaszezyk, I. 1992. Turonian through Santonian deposits of the Central Polish Uplands: their facies development, inoceramid paleontology and stratigraphy. Acta Geologica Polonica, 42: $1-122$.

Woodroof, P. B. 1981. Faunal and stratigraphic studies in the Turonian of the Anglo-Paris Basin. Unpublished DPhil thesis, Oxford University.

Wright, C. W. \& Kennedy, W. J. 1981. The Ammonoidea of the Plenus Marls and the Middle Chalk. Monographs of the Palaeontographical Society, 134: 148pp. 